\title{
Front Matter: Volume 7806
}

, "Front Matter: Volume 7806," Proc. SPIE 7806, Penetrating Radiation Systems and Applications XI, 780601 (7 October 2010); doi:

10.1117/12.877485

SPIE Event: SPIE Optical Engineering + Applications, 2010, San Diego, California, SPIE. United States 


\title{
PROCEEDINGS OF SPIE
}

\section{Penetrating Radiation Systems and Applications XI}

\author{
F. Patrick Doty \\ H. Bradford Barber \\ Hans Roehrig \\ Richard C. Schirato \\ Editors
}

2-5 August 2010

San Diego, California, United States

Sponsored and Published by

SPIE

Volume 7806 
The papers included in this volume were part of the technical conference cited on the cover and title page. Papers were selected and subject to review by the editors and conference program committee. Some conference presentations may not be available for publication. The papers published in these proceedings reflect the work and thoughts of the authors and are published herein as submitted. The publisher is not responsible for the validity of the information or for any outcomes resulting from reliance thereon.

Please use the following format to cite material from this book:

Author(s), "Title of Paper," in Penetrating Radiation Systems and Applications XI, edited by F. Patrick Doty, H. Bradford Barber, Hans Roehrig, Richard C. Schirato, Proceedings of SPIE Vol. 7806 (SPIE, Bellingham, WA, 2010) Article CID Number.

ISSN 0277-786X

ISBN 9780819483027

Published by

SPIE

P.O. Box 10, Bellingham, Washington $98227-0010$ USA

Telephone +1 3606763290 (Pacific Time) · Fax +1 3606471445

SPIE.org

Copyright @ 2010, Society of Photo-Optical Instrumentation Engineers

Copying of material in this book for internal or personal use, or for the internal or personal use of specific clients, beyond the fair use provisions granted by the U.S. Copyright Law is authorized by SPIE subject to payment of copying fees. The Transactional Reporting Service base fee for this volume is $\$ 18.00$ per article (or portion thereof), which should be paid directly to the Copyright Clearance Center (CCC), 222 Rosewood Drive, Danvers, MA 01923. Payment may also be made electronically through CCC Online at copyright.com. Other copying for republication, resale, advertising or promotion, or any form of systematic or multiple reproduction of any material in this book is prohibited except with permission in writing from the publisher. The CCC fee code is 0277-786X/10/\$18.00.

Printed in the United States of America.

Publication of record for individual papers is online in the SPIE Digital Library.

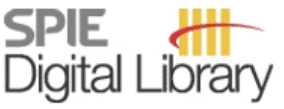

SPIEDigitalLibrary.org

Paper Numbering: Proceedings of SPIE follow an e-First publication model, with papers published first online and then in print and on CD-ROM. Papers are published as they are submitted and meet publication criteria. A unique, consistent, permanent citation identifier (CID) number is assigned to each article at the time of the first publication. Utilization of CIDs allows articles to be fully citable as soon they are published online, and connects the same identifier to all online, print, and electronic versions of the publication. SPIE uses a six-digit CID article numbering system in which:

- The first four digits correspond to the SPIE volume number.

- The last two digits indicate publication order within the volume using a Base 36 numbering system employing both numerals and letters. These two-number sets start with 00, 01, 02, 03, 04 , 05, 06, 07, 08, 09, OA, OB ... 0Z, followed by 10-1Z, 20-2Z, etc.

The CID number appears on each page of the manuscript. The complete citation is used on the first page, and an abbreviated version on subsequent pages. Numbers in the index correspond to the last two digits of the six-digit CID number. 


\section{Contents}

$\checkmark \quad$ Conference Committee

SESSION 1 MEDICAL APPLICATIONS I

780603 Development of radiation dose reduction techniques for cadmium zinc telluride detectors in molecular breast imaging (Invited Paper) [7806-02]

M. K. O'Connor, C. B. Hruska, A. Weinmann, A. Manduca, D. J. Rhodes, Mayo Clinic (United States)

780604 Continued development of room temperature semiconductor nuclear detectors (Invited Paper) [7806-03]

H. Kim, L. Cirignano, A. Churilov, G. Ciampi, A. Kargar, W. Higgins, P. O'Dougherty, S. Kim, M. R. Squillante, K. Shah, Radiation Monitoring Devices, Inc. (United States)

\section{SESSION 2 GENERAL APPLICATIONS}

780607 A portable neutron spectroscope (NSPECT) for detection, imaging, and identification of nuclear material (Invited Paper) [7806-06]

J. M. Ryan, C. Bancroft, P. Bloser, U. Bravar, The Univ. of New Hampshire (United States);

D. Fourguette, Michigan Aerospace Corp. (United States); C. Frost, The Univ. of New Hampshire (United States); L. Larocque, Michigan Aerospace Corp. (United States); M. L. McConnell, J. Legere, The Univ. of New Hampshire (United States); J. Pavlich, G. Ritter, G. Wassick, Michigan Aerospace Corp. (United States); J. Wood, R. Woolf, The Univ. of New Hampshire (United States)

\section{SESSION 3 SCINTILLATORS}

7806 OC Imaging penetrating radiation through ion photon emission microscopy (Invited Paper) [7806-11]

K. Hattar, J. V. Branson, C. J. Powell, G. Vizkelethy, Sandia National Labs. (United States);

P. Rossi, Sandia National Labs. (United States) and INFN, Univ. degli Studi di Padova (Italy);

B. L. Doyle, Sandia National Labs. (United States)

7806 OE Atomistic models for scintillator discovery [7806-13]

X. W. Zhou, F. P. Doty, P. Yang, Sandia National Labs. (United States)

\section{SESSION 4 MEDICAL APPLICATIONS II}

7806 OF Potential for focused beam orthovoltage therapy [7806-14]

D. N. Mahato, C. A. MacDonald, Univ. at Albany (United States) 
7806 OG Liquid detection trial with $x$-ray diffraction [7806-15]

G. Harding, H. Fleckenstein, S. Olesinski, G. Zienert, Morpho Detection GmbH (Germany)

$7806 \mathrm{OH} \quad$ Medical color displays and their color calibration: investigations of various calibration methods, tools, and potential improvement in color difference $\Delta E$ [7806-16]

H. Roehrig, S. F. Hashmi, W. J. Dallas, E. A. Krupinski, K. Rehm, The Univ. of Arizona (United States); J. Fan, GE Healthcare (United States)

7806 이 Experimental comparison of next-generation XDi topologies [7806-17]

G. Harding, D. Kosciesza, S. Olesinski, H. Strecker, Morpho Detection GmbH (Germany)

7806 OK Studies of $\mathrm{x}$-ray-induced thermally stimulated luminescence properties of $\mathrm{Mn}^{2+}$-doped $\mathrm{MgSO}_{4}$ by using glow-curve deconvolution technique [7806-19]

J. Manam, S. Das, Indian School of Mines (India)

\section{POSTER SESSION}

7806 OL CZT smart dicing strategy for cost reduction using defect imaging and random-access machining [7806-20]

J. E. Tkaczyk, K. Andreini, T. Zhang, K. G. Harding, G. Abramovich, Y. Williams, C. A. Nafis, W. Zhang, GE Global Research (United States)

\section{ADDITIONAL PAPER}

7806 OM Aliovalent Doping of $\mathrm{CeBr}_{3}$ [7806-22]

M. J. Harrison, P. Ugorowski, C. Linnick, S. Brinton, D. S. McGregor, Kansas State Univ. (United States); F. P. Doty, Sandia National Labs. (United States); S. Kirpatrcik, D. F. Bahr, Washington State Univ. (United States)

Author Index 


\title{
Conference Committee
}

\author{
Program Track Chair
}

Carolyn A. MacDonald, University at Albany (United States)

Conference Chairs

F. Patrick Doty, Sandia National Laboratories (United States)

H. Bradford Barber, The University of Arizona (United States)

Hans Roehrig, The University of Arizona (United States)

Richard C. Schirato, Los Alamos National Laboratory (United States)

Conference Cochair

Douglas J. Wagenaar, Gamma Medica-Ideas, Inc. (United States)

Program Committee

Zane W. Bell, Oak Ridge National Laboratory (United States)

Liying Chen, The University of Arizona (United States)

Gary P. Grim, Los Alamos National Laboratory (United States)

Geoffrey Harding, GE Security Germany GmbH (Germany)

Ralph B. James, Brookhaven National Laboratory (United States)

Denny L. Lee, DxRay, Inc. (United States)

Vivek V. Nagarkar, Radiation Monitoring Devices, Inc. (United States)

Stephen A. Payne, Lawrence Livermore National Laboratory (United States)

Ladislav Pina, Czech Technical University in Prague (Czech Republic)

Eiichi Sato, Iwate Medical University (Japan)

Irina Shestakova, Radiation Monitoring Devices, Inc. (United States)

Michael R. Squillante, Radiation Monitoring Devices, Inc.

(United States)

Session Chairs

1 Medical Applications I

H. Bradford Barber, The University of Arizona (United States)

2 General Applications

Douglas J. Wagenaar, Gamma Medica-Ideas, Inc. (United States) 
3 Scintillators

Hans Roehrig, The University of Arizona (United States)

4 Medical Applications II

F. Patrick Doty, Sandia National Laboratories (United States) 